\title{
Evaluation and Comparison of the Quality of Two Crude Oils at Dura Oil Refinery
}

\author{
Wedad H. Al-Dahhan \\ Chemistry Department, College of Science, Al-Nahrain University, Baghdad-Iraq. \\ E-Mail: dahan62@yahoo.com.
}

\begin{abstract}
Two types of crude oil at Dura oil refinery were selected and tested using the physical properties: Boiling point, Density, Pour point, Surface tension and Aniline point in addition to the calculated results: API gravity, $\mathrm{Kw}$ factor and Correlation index in order to determine the characteristics of oils and comparison between them. A special distillation curves were obtained according to ASTM2892 distillation method for the tested crudes to calculate the percentages and quantities of each crude oil derivatives to support the preliminary data of the physical properties to indicate the characteristics in terms of being paraffinic, naphthenic or aromatic as an addition comparison between crude oils used. It turned out through the entire results that the properties of crude oil (A) shows that it is heavier and the greater the concentration of naphthenes and aromatics than in the crude oil (B) and the same concept, the (B) more paraffinic than (A).
\end{abstract}

Keywords: Crude oil, Crude Oil Properties, Distillate composition, Distillation curve.

\section{Introduction}

Petroleum is a naturally mixture of hydrocarbons, generally in the liquid state, that may also include compounds of sulfur, nitrogen, oxygen, and metals and other elements [1]. Crude oils are highly valued because they are feedstocks for a wide variety of products, including gasoline, diesel fuel, lubricant oil, hydraulic oil, and liquefied petroleum gas. Many properties of crude oil are dependent on their source [2].

Crude oil or petroleum representing several classes of compounds, the most important of these being alkanes, naphthenes and aromatics [3]. These classes are not sharply divided as the aromatic compounds often contain alkane substituents and many of the ring structures are mixed aromatics and naphthenes. They also have heterocyclic compounds of oxygen, sulfur, nitrogen, phosphorus and trace amounts of metals especially vanadium, nickel and iron. These constituents may significantly affect the refining processes as well as the analysis procedures [4]. Oils with low carbon, high hydrogen, and high API (American Petroleum Institute) gravity are usually rich in paraffins and tend to yield greater proportions of gasoline and light petroleum products; those with high carbon, low hydrogen, and low API gravities are usually rich in aromatics. The former category is known as light crudes and the latter as heavy crudes [5].

\section{Experimental}

\subsection{API (American Petroleum Institute)}

It is generally use the API gravity to specify the specific gravity (SG) of the crude oil as $\mathrm{API}=(141.5 / \mathrm{SG})-131.5 . \mathrm{SG}$ is the specific gravity defined as the ratio of the density of the crude oil to the density of water both at $15.6^{\circ} \mathrm{C}\left(60^{\circ} \mathrm{F}\right)$. The API gravity varies from less than 10 for very heavy crudes, to between 10 and 30 for heavy crudes, to between 30 and 40 for medium crudes, and to above 40 for light crudes [6]. Density, specific gravity at $20^{\circ} \mathrm{C}$ has been determined according to ASTM 1217.

\subsection{Characterization Factor}

There are several correlation between yield and the aromaticity and paraffinicity of crude oils, but the two most widely used are UOP or Watson "characterization factor" (Kw) and the Bureau of Mines correlation index (CI).

$$
\begin{aligned}
& \mathrm{Kw}=(\mathrm{TB}){ }^{1 / 3} / \mathrm{G} \ldots \ldots \ldots \ldots \ldots \ldots \ldots \ldots \ldots \ldots \ldots \ldots \\
& \mathrm{CI}=87552 / \mathrm{TB}+473.7 \mathrm{G}-456.8
\end{aligned}
$$

Where (TB) is the average boiling point in degrees Rankine $\left({ }^{\circ} \mathrm{F}+460\right)$ and $(\mathrm{G})$ is the specific gravity $60^{\circ} / 60^{\circ} \mathrm{F}$ [7]. Characterization factor has been shown to be additive on a 
weight basis. It was originally devised to show the thermal cracking characteristics of heavy oils, thus highly paraffin oils have $\mathrm{K}$ in the range 12.5 to 13.0 and cyclic (naphthene) oils have $\mathrm{K}$ in the range 10.5 to 12.5 [8].

The CI scale is based upon straight-chain paraffins having a $\mathrm{CI}$ value of (0) and benzene having a CI value of (100).

The CI values are not quantitative, but the lower the CI value, the greater the concentration of paraffin hydrocarbons in the fraction, and higher the CI value, the greater the concentration of naphthenes and aromatics [7].

\subsection{Viscosity}

The viscosity of crude is an important physical property that controls and influences the flow of oil through porous media and pipes. The viscosity, in general, is defined as the internal resistance of the fluid to flow [9]. Ostwald viscometer, also known as U-tube viscometer or capillary viscometer is a device used to measure the viscosity of the liquid with a known density. The method of determining viscosity with this instrument consists of measuring the time for a known volume of the liquid (the volume contained between the marks $\mathrm{A}$ and $\mathrm{B}$ ) to flow through the capillary under the influence of gravity. Ostwald viscometers named after the German chemist Wilhelm Ostwald (1853-1932). The instrument must first be calibrated with materials of known viscosity such as pure (deionized) water. Knowing the value of viscosity of one liquid, one can calculate the viscosity of other liquid.

$$
\eta_{1} / \eta_{2}=\rho_{1} t_{1} / \rho_{2} t_{2}
$$

Where $\eta_{1}$ and $\eta_{2}$ are viscosity coefficients of the liquid and water, and $\rho_{1}$ and $\rho_{2}$ [10].The viscosity has been measured according to ASTM-D 445 method.

\subsection{Pour Point}

The lowest temperature at which a hydrocarbon fraction is observed to pour when cooled under prescribed conditions.

The pour point of a sample is determined to be 3 degrees Celsius above the point at which a sample can be horizontally held and no movement occurs for five seconds. For whole crudes that have pour points greater than$36^{\circ} \mathrm{C}$, a new method has been developed (ASTM-D 5853) [11]. The pour point has been analyzed according to this method.

\subsection{Surface Tension and Interfacial Tension}

Interfacial tension is the force of attraction between the molecules at the interface of two fluids. At the air/liquid interface, this force is often referred to as surface tension. The SI units for interfacial tension are millinewtons per meter $(\mathrm{mN} / \mathrm{m})$. These are equivalent to the former units of dynes per centimeter (dyne/cm).The surface tension of oil, together with its viscosity, affects the rate at which an oil spill spreads. Air/oil and oil/water interfacial tensions can be used to calculate a spreading coefficient which gives an indication of the tendency for the oil to spread [12].

The Surface Tension has been analyzed according to ASTM 1331.

\subsection{Aniline Point}

The quality of various petroleum fuels depends on their composition and types of hydrocarbons present in the mixture. Octane number is one of the characteristics. Aniline point (AP) is another characteristic of petroleum fractions that indicates the degree of aromaticity of hydrocarbon mixtures. Aniline point is defined as the lowest temperature at which equal volumes of aniline and the sample become completely soluble. As amount of aromatics in a petroleum fraction increase the aniline point decreases. Therefore, the aniline point is a parameter that is highly related to the hydrocarbon types in petroleum fractions [13].The aniline point has been measured according to ASTM-D 611.

\subsection{Distillation}

Having in mind that crude oil cost accounts for more than $80 \%$ of refinery expenditure the proper operation of crude distillation unit has great impact on refinery profitability [14].

For the characterization of crude oils, there are several sources of information, the best of which are the experimental assays. In distillation unit the crude oil is separated by heating, identifying the light components which are sequentially produced at different 
temperatures [15]. Refining of crude oils or petroleum essentially consists of primary separation processes and secondary conversion processes. The petroleum refining process is the separation of the different hydrocarbons present in the crude oil into useful fractions and the conversion of some of the hydrocarbons into products having higher quality performance. Atmospheric and vacuum distillation of crude oils is the main primary separation processes producing various straight run products, e.g., gasoline to lube oils/vacuum gas oils (VGO). These products, particularly the light and middle distillates, i.e., gasoline, kerosene and diesel are more in demand than their direct availability from crude oils, all over the world [16].

\subsection{Distillation curve measurement}

Simply stated, the distillation curve is a graphical depiction of the boiling temperature of a fluid (or fluid mixture) plotted against the volume fraction distilled [17]. The most common presentation of the distillation curve is a plot of the boiling temperature (at ambient pressure) against volume fraction.

The test method for the distillation of petroleum products at atmospheric pressure, ASTM-D 86, provides the approach to measurement [18]. The data obtained with ASTM- D 86 are the initial boiling point (IBP), the temperature at predetermined distillate volume fractions, as well as the final boiling point (FBP). The ASTM D 2892 method is designated for any petroleum mixture with an initial boiling point below 400 ${ }^{\circ} \mathrm{C}$, and specifies that the atmospheric pressure section of the four-part distillation procedure be discontinued at $310^{\circ} \mathrm{C}$ to avoid "significant cracking" [19].

The atmospheric distillation of crude oil samples (A \& B) recovered from Dura oil refinery has been carried out in distillation apparatus, according to ASTM-D 2892. Crude oil fractions determined according to standard distillation curve Fig.(1) and the related fractions data Table (1).



Fig.(1): Standard fractions limits at crude oil distillation curve [19]. 
Table (1)

Some common cut points [19].

\begin{tabular}{||c|c||c|c||c|c||c||}
\hline $\begin{array}{c}\text { Temperature } \\
\text { Range }\end{array}$ & $\begin{array}{c}\text { Under } \\
\left(32.2{ }^{\circ} \mathrm{C}\right)\end{array}$ & $\begin{array}{c}(32.2-104.4) \\
{ }^{\circ} \mathrm{C}\end{array}$ & $\begin{array}{c}(104.4-157) \\
{ }^{\circ} \mathrm{C}\end{array}$ & $\begin{array}{c}(157-232) \\
{ }^{\circ} \mathrm{C}\end{array}$ & $\begin{array}{c}(232-426) \\
{ }^{\circ} \mathrm{C}\end{array}$ & $\begin{array}{c}\left(426{ }^{\circ} \mathrm{C}\right) \\
\text { and up }\end{array}$ \\
\hline \hline Fraction Type & $\begin{array}{c}\text { Butane } \\
\text { and } \\
\text { lighter }\end{array}$ & Gasoline & Naphtha & Kerosene & Gas oil & $\begin{array}{c}\text { Residuum } \\
\text { (including } \\
\text { asphalt) }\end{array}$ \\
\hline
\end{tabular}

\section{Results and Discussion}

\subsection{Characterizes the range of variation of} the properties of the crude oils.

In general all the characteristics listed in Table (2), indicate that crude oil (B) lighter than crude oil (A) due to its lower (density, pour point, viscosity and surface tension), and in particular crude oil (A) more aromatic than the crude oil (B) according to its higher $(\mathrm{Kw})$ and lower $(\mathrm{CI})$ values or the latter more paraffinic from (A) for the same reason.

Table (2)

Characterizes the range of variation of the properties of the crude oils $(A \& B)$.

\begin{tabular}{|c|c|c|c|c|c|c|c|c|c|}
\hline $\begin{array}{l}\text { Crude } \\
\text { Type }\end{array}$ & $\begin{array}{c}\text { Density } \\
\text { g/cm } \\
\left(20^{\circ} \mathrm{C}\right)\end{array}$ & $\begin{array}{c}\text { Density } \\
\mathrm{g} / \mathrm{cm}^{3} \\
\left(15.6^{\circ} \mathrm{C}\right)\end{array}$ & $\begin{array}{c}\text { Specific } \\
\text { gravity } \\
\left(15.6^{\circ} \mathrm{C}\right)\end{array}$ & $\begin{array}{c}\text { API } \\
\text { gravity }\end{array}$ & $\begin{array}{l}\text { Pour } \\
\text { Point } \\
\left({ }^{\circ} \mathrm{C}\right)\end{array}$ & $\begin{array}{c}\text { Dynamic } \\
\text { Viscosity } \\
\text { at } 20^{\circ} \mathrm{C} \\
(\mathrm{cp}) \\
\end{array}$ & $\begin{array}{l}\text { Surface } \\
\text { Tension } \\
\text { at } 20^{\circ} \mathrm{C} \\
\left(\mathrm{m} \mathrm{Nm}^{-1}\right) \\
\end{array}$ & $\begin{array}{c}K w \\
\text { Factor } \\
\left({ }^{o} R\right)\end{array}$ & $\begin{array}{c}\text { Correlation } \\
\text { Index }(C I)\end{array}$ \\
\hline A & 0.90 & 0.92 & 0.92 & 22.30 & -10 & 34.19 & 32.91 & 10.76 & 69.03 \\
\hline $\mathrm{B}$ & 0.82 & 0.84 & 0.84 & 36.95 & -21 & 15.08 & 26.27 & 11.42 & 47.56 \\
\hline
\end{tabular}

\subsection{Distillation results for crude oils}

The distillation results listed in Tables $(3,4)$ and Fig.(2) for crude oils (A) and (B) indicates that crude oil (B) lighter than crude oil (A) along distillation process (from first drop to $50 \%$ volume distillate). This conclusion based mainly on the density results for distillation products.

Table (3)

Distillation results for crude oil (A).

\begin{tabular}{|c|c|c|c|c|c|c|c|c|c|}
\hline $\begin{array}{c}\text { Cumulative } \\
\text { Volume \% }\end{array}$ & $\begin{array}{c}\text { Boiling } \\
\text { Point } \\
{ }^{\circ} \mathrm{C} \\
\end{array}$ & $\begin{array}{c}\text { Density } \\
\mathrm{g} / \mathrm{cm}^{3} \\
\left(20^{\circ} \mathrm{C}\right) \\
\end{array}$ & $\begin{array}{c}\text { Density } \\
\mathrm{g} / \mathrm{cm}^{3} \\
\left(15.6^{\circ} \mathrm{C}\right) \\
\end{array}$ & $\begin{array}{c}\text { Specific } \\
\text { gravity } \\
\left(15.6^{\circ} \mathrm{C}\right) \\
\end{array}$ & $\begin{array}{c}\text { API } \\
\text { gravity }\end{array}$ & $\begin{array}{c}\text { Aniline } \\
\text { point } \\
\left({ }^{\circ} \mathrm{C}\right) \\
\end{array}$ & $\begin{array}{c}\text { Pour } \\
\text { Point } \\
\left({ }^{\circ} \mathrm{C}\right) \\
\end{array}$ & $\begin{array}{c}K w \\
\text { Factor } \\
\left({ }^{\circ} R\right) \\
\end{array}$ & $\begin{array}{l}\text { Correlation } \\
\text { Index }(C I)\end{array}$ \\
\hline First drop & 115 & - & - & - & - & & - & - & - \\
\hline 5 & 158 & 0.76 & 0.78 & 0.78 & 54.68 & 60.1 & - & 12.69 & 2.72 \\
\hline 10 & 192 & 0.78 & 0.80 & 0.80 & 49.91 & 56.3 & -28.1 & 12.38 & 12.19 \\
\hline 15 & 216 & 0.81 & 0.83 & 0.83 & 43.19 & 52.1 & - & 11.93 & 26.40 \\
\hline 20 & 245 & 0.85 & 0.86 & 0.86 & 34.97 & 50.5 & -21.1 & 11.51 & 40.61 \\
\hline 25 & 288 & 0.87 & 0.89 & 0.89 & 31.14 & 47.2 & - & 11.12 & 54.82 \\
\hline 30 & 292 & 0.89 & 0.90 & 0.90 & 27.48 & 42.9 & -10.2 & 11.00 & 59.56 \\
\hline 35 & 310 & 0.91 & 0.92 & 0.92 & 22.30 & 40.8 & - & 10.67 & 69.03 \\
\hline 40 & 318 & 0.92 & 0.93 & 0.93 & 20.65 & 40.0 & -6.3 & 10.64 & 73.77 \\
\hline 45 & 322 & 0.92 & 0.93 & 0.93 & 24.00 & 38.0 & - & 10.64 & 73.77 \\
\hline 50 & 330 & 0.93 & 0.94 & 0.94 & 24.00 & 34.6 & -3.0 & 10.53 & 78.50 \\
\hline
\end{tabular}


Table (4)

Distillation results for crude oil (B).

\begin{tabular}{|c|c|c|c|c|c|c|c|c|c|}
\hline $\begin{array}{c}\text { Cumulative } \\
\text { Volume } \\
\%\end{array}$ & $\begin{array}{c}\text { Boiling } \\
\text { Point } \\
\left({ }^{\circ} \mathrm{C}\right) \\
\end{array}$ & $\begin{array}{c}\text { Density } \\
\mathrm{g} / \mathrm{cm}^{3}(20 \\
\left.{ }^{\circ} \mathrm{C}\right) \\
\end{array}$ & $\begin{array}{c}\text { Density } \\
\text { g/cm3 } \\
\left(15.6^{\circ} \mathrm{C}\right) \\
\end{array}$ & $\begin{array}{c}\text { Specific } \\
\text { gravity } \\
\left(15.6^{\circ} \mathrm{C}\right) \\
\end{array}$ & $\begin{array}{c}\text { API } \\
\text { gravity }\end{array}$ & $\begin{array}{c}\text { Aniline } \\
\text { point } \\
\left({ }^{\circ} \mathrm{C}\right) \\
\end{array}$ & $\begin{array}{c}\text { Pour } \\
\text { Point } \\
\left({ }^{\circ} \mathrm{C}\right) \\
\end{array}$ & $\begin{array}{c}\boldsymbol{K} w \\
\text { Factor } \\
\left({ }^{\circ} \mathrm{R}\right) \\
\end{array}$ & $\begin{array}{l}\text { Correlation } \\
\text { Index (CI) }\end{array}$ \\
\hline First drop & 70 & - & - & - & - & - & - & - & - \\
\hline 5 & 107 & 0.66 & 0.68 & 0.68 & 76.58 & 68.2 & - & 13.78 & - \\
\hline 10 & 124 & 0.68 & 0.70 & 0.70 & 70.64 & 66.3 & -48.9 & 13.38 & - \\
\hline 15 & 140 & 0.71 & 0.72 & 0.72 & 65.02 & 62.6 & - & 13.01 & - \\
\hline 20 & 152 & 0.73 & 0.75 & 0.75 & 57.16 & 59.3 & -40.2 & 12.49 & 4.94 \\
\hline 25 & 170 & 0.75 & 0.77 & 0.77 & 52.26 & 58.0 & - & 12.17 & 14.41 \\
\hline 30 & 188 & 0.78 & 0.80 & 0.80 & 45.37 & 50.2 & -32.6 & 11.71 & 28.63 \\
\hline 35 & 208 & 0.80 & 0.83 & 0.83 & 38.98 & 45.0 & - & 11.29 & 42.84 \\
\hline 40 & 228 & 0.81 & 0.85 & 0.85 & 34.97 & 41.1 & -25.3 & 11.02 & 52.31 \\
\hline 45 & 250 & 0.84 & 0.87 & 0.87 & 31.14 & 40.1 & - & 10.77 & 61.79 \\
\hline 50 & 270 & 0.86 & 0.91 & 0.91 & 23.99 & 38.0 & -12.1 & 10.30 & 80.73 \\
\hline
\end{tabular}

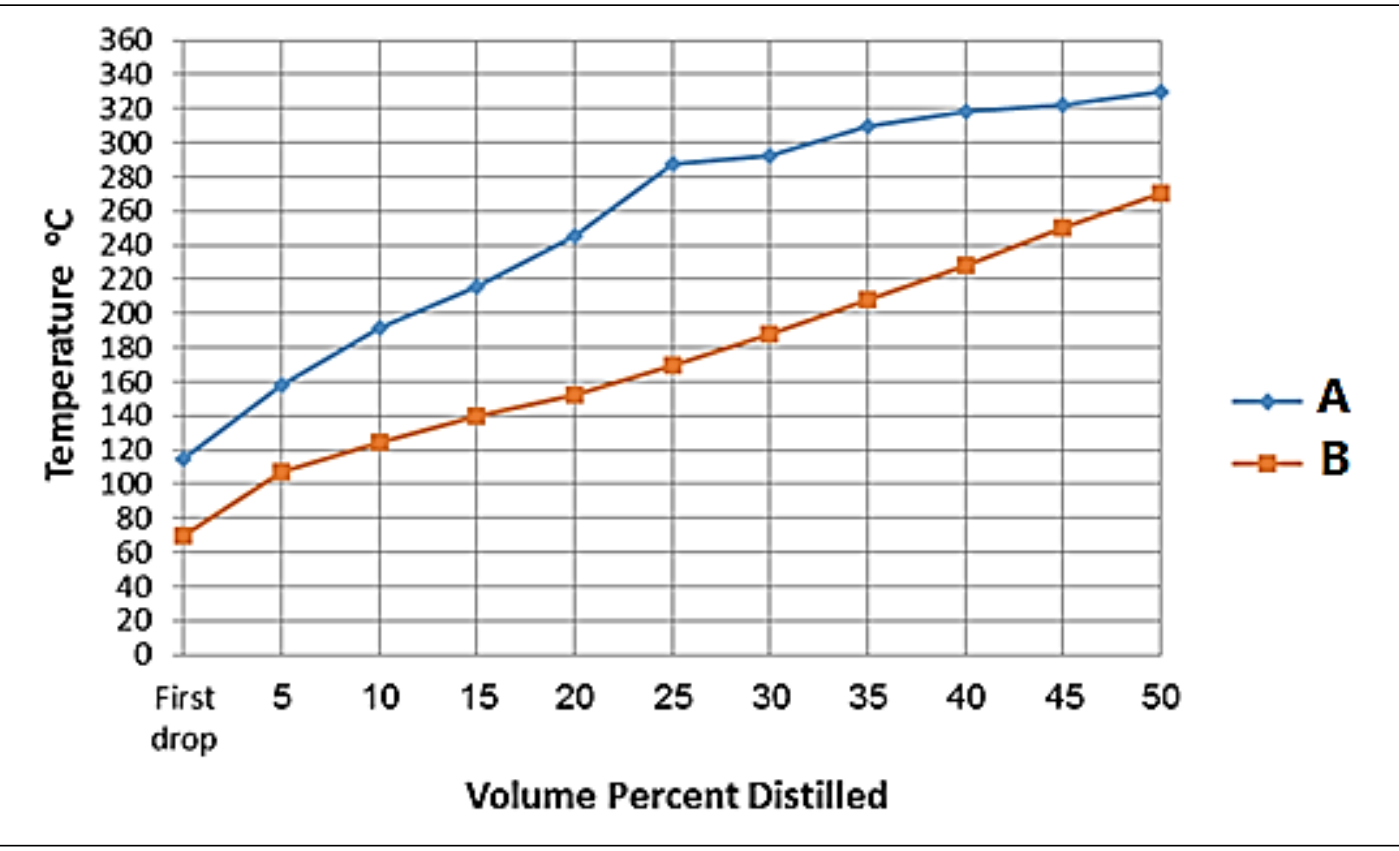

Fig.(2): Distillation curve for two crude oils (A\& B).

To calculate the percentage or quantities of oil derivatives (Gasoline, Naphtha, Kerosene and Gas oil) based on the data presented in Table (1) and Fig.(3), crude oils (A) and (B) gave oil products within the limits of atmospheric distillation a quantities shown in Table (5), which refers to the abundance of light derivatives (Gasoline and Naphtha) in crude (B) more than it is in (A), which has an abundance of gas oil (33\%). 


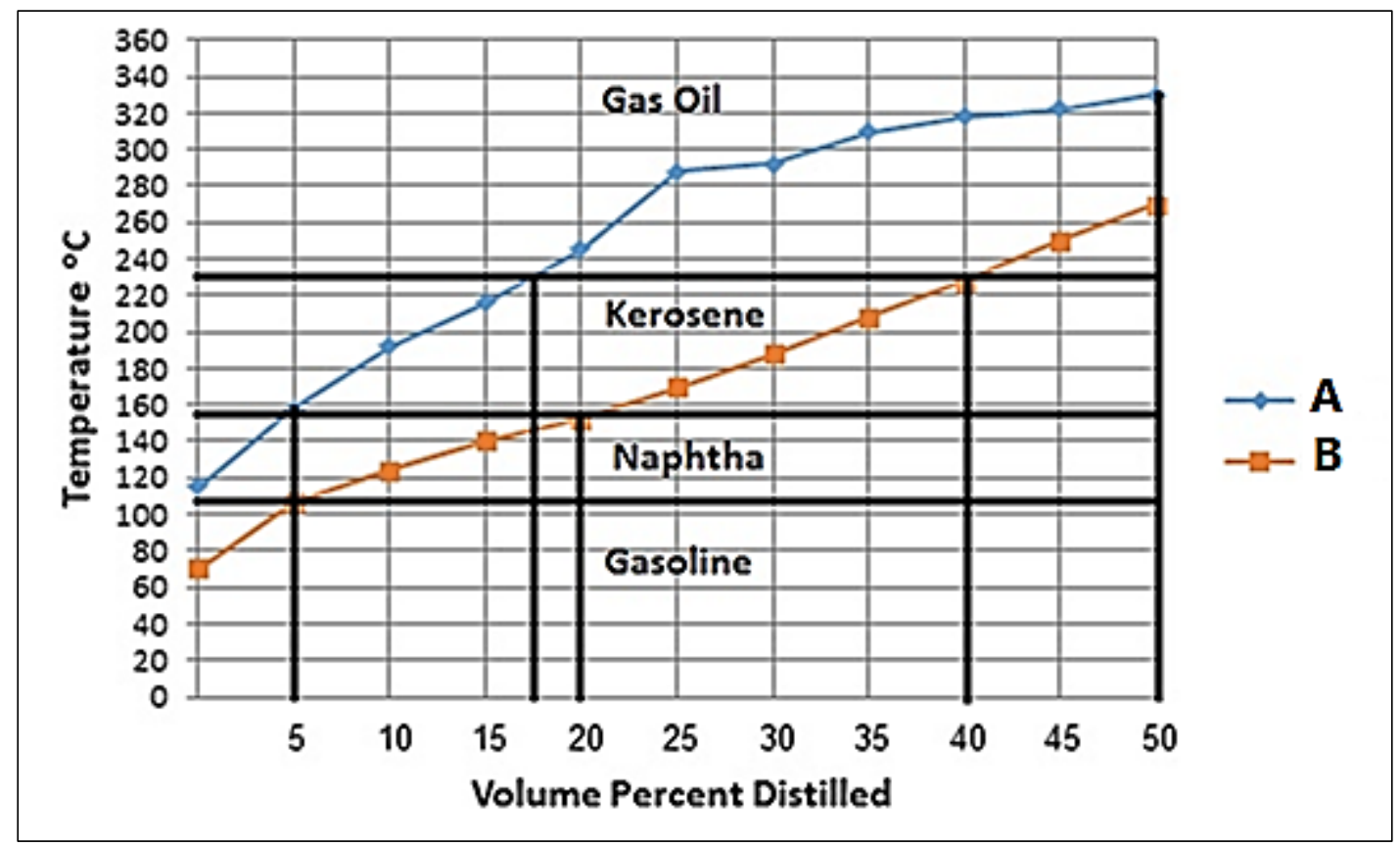

Fig.(3): Straight run crude oil fractions distribution on crude oils distillation curve.

Table (5)

Straight run crude oil fractions from crude oils distillation curve.

\begin{tabular}{|c||c|c||c||c|}
\hline \multirow{2}{*}{$\begin{array}{c}\text { Fractions } \\
\text { Crude Oil }\end{array}$} & Gasoline & Naphtha & Kerosene & Gas oil \\
\cline { 2 - 5 } & \multicolumn{4}{|c||}{ Volume Percent Distilled } \\
\hline A & - & 5 & 12 & 33 \\
\hline \hline B & 5 & 15 & 20 & 10 \\
\hline \hline & The approximate volume (liter) distilled from one barrel \\
\hline \hline A & - & 7.95 & 19.08 & 52.47 \\
\hline B & 7.95 & 23.85 & 31.8 & 15.7 \\
\hline
\end{tabular}

It is possible to make use of temperature difference along the distillation process for crude oil (A) and (B) shown in Fig. (6) and Table (6) to explain the characteristics of the products. There is slightly temperature difference at the beginning of distillation $(0-10) \%$ (A gives about 5\% Naphtha $+5 \%$ Kerosene while B 5\% Gasoline $+5 \%$ Naphtha) and at the end of distillation in the range of (40-50) \% (A \& B both gives about $10 \%$ gas oil) but it shows higher temperature deviation in the range of (10-40)\% distilled products, as a result crude (B) gives more light distillate $(10 \%$ Naphtha $+20 \%$ Kerosene $)$ while crude (A) gives about $(8 \%$ Kerosene + $22 \%$ gas oil) Table (5) Fig.(4,5).

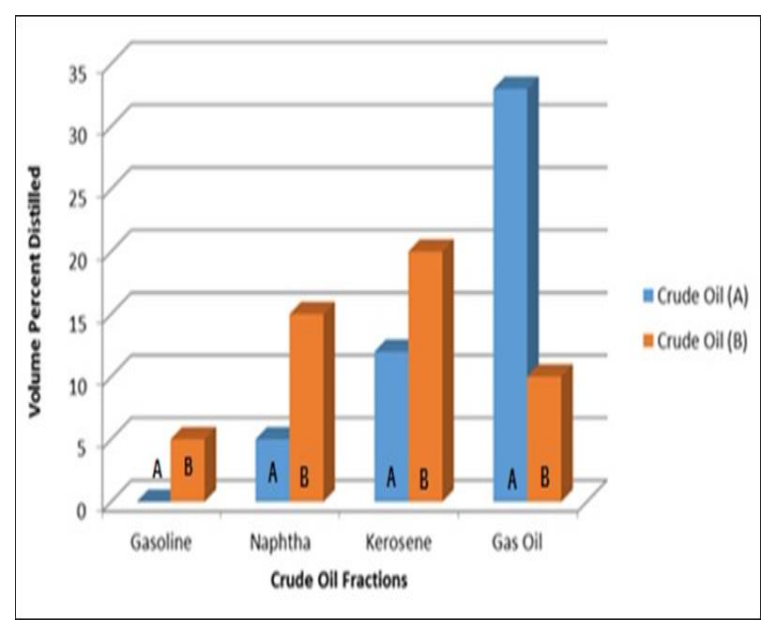

Fig.(4): Fractions volume percent distilled from crude oils $A \& B$. 


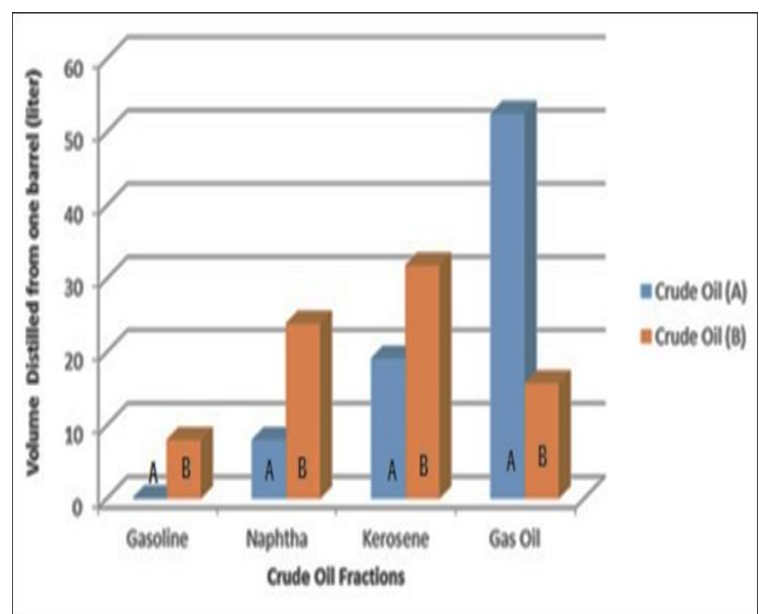

Fig.(5): Fractions volume distilled from one barrel crude oils $A \& B$.

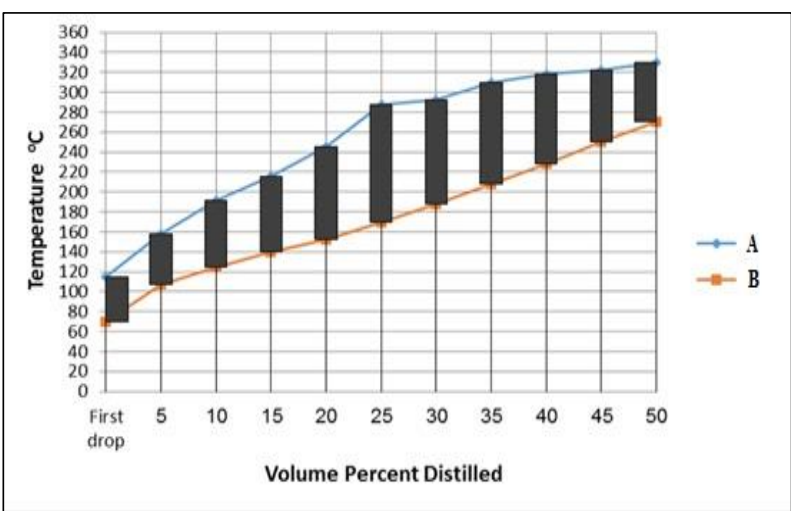

\section{Fig.(6): Temperature differences between the} two crudes along the distillation curve.

Table (6)

Temperature differences between the two crudes $(A \& B)$ along the distillation curve.

\begin{tabular}{|c||c|c||c||c||c||c||c||c|c||c||c|}
\hline Volume \% Distilled & First drop & 5 & 10 & 15 & 20 & 25 & 30 & 35 & 40 & 45 & 50 \\
\hline \hline Temperature differences $\left({ }^{\circ} \mathbf{C}\right)$ & 45 & 51 & 68 & 76 & 93 & 118 & 104 & 102 & 90 & 72 & 60 \\
\hline
\end{tabular}

According to aniline points for crude oil fractions (A\&B) Fig.(7) in addition to $\mathrm{Kw}$ factor data Fig.(8) and correlation index Fig.(9) crude oil (A) shows that it has naphthenic or aromatic components more than crude (B) (see sec.1.3).
3.3. Aniline point results for crude oil fractions (A \& B)

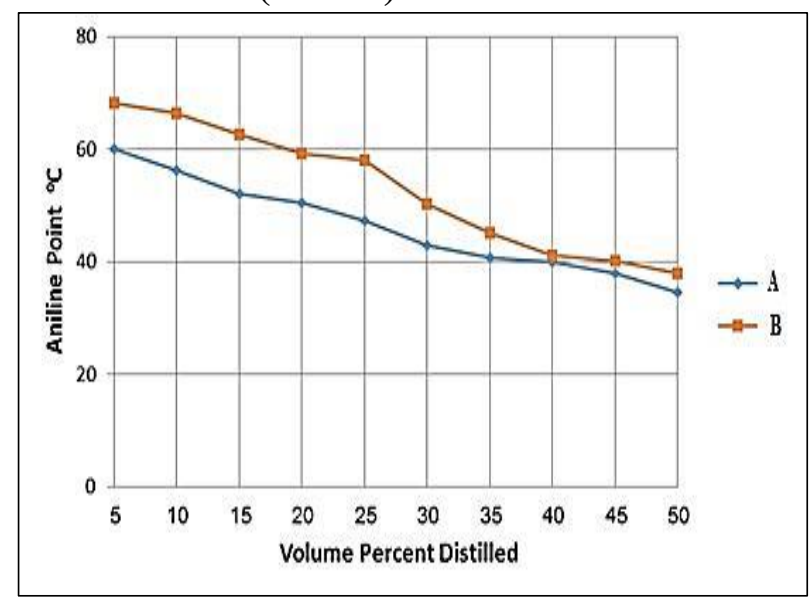

Fig.(7): Aniline points for crude oil fractions $(A \& B)$. 

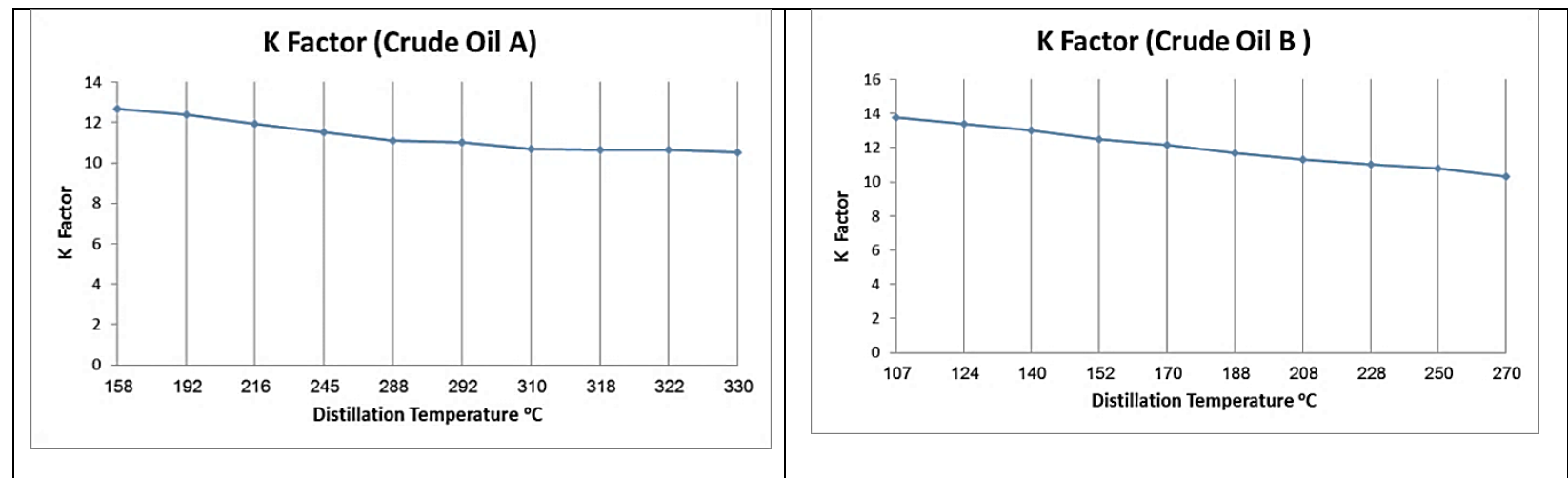

Fig.(8): $K$ factor distribution along distillation temperature for crude oils $A \& B$.
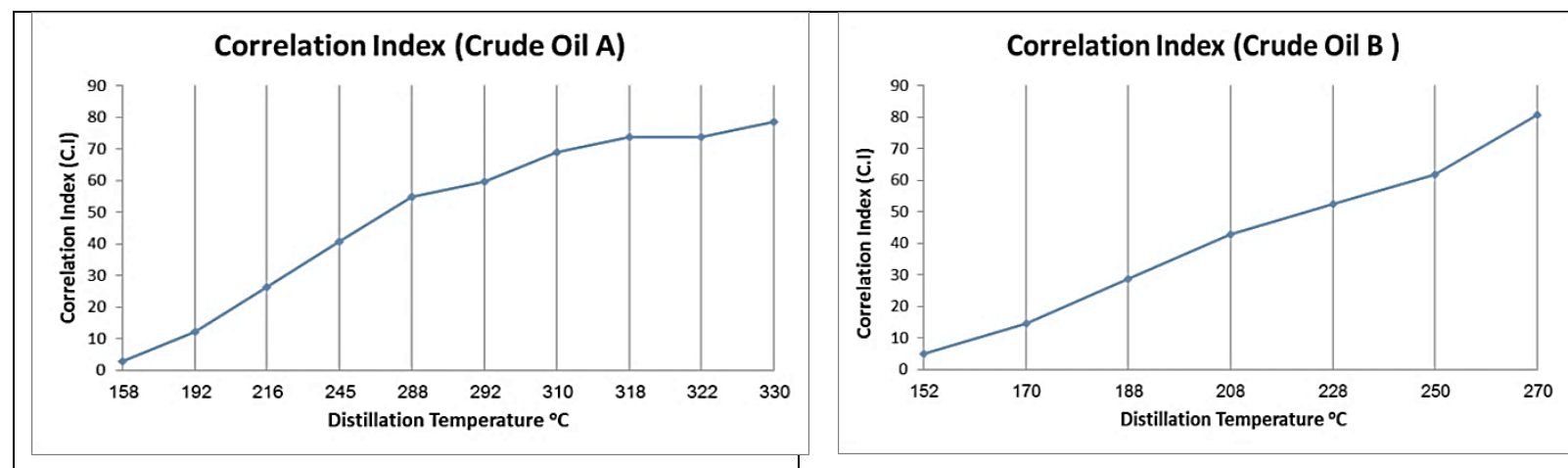

Fig.(9): Correlation index distribution along distillation temperature for crude oils $A \& B$.

3.4. Density, API, Correlation index and Kw factor distribution along distillation temperature for crude oils $A \& B$

Density distribution Fig.(10) shows that crude oil (A) lighter than (B) along the temperature range for crude oil (A)(158$330)^{\circ} \mathrm{C}$ and $(107-270)^{\circ} \mathrm{C}$ for crude oil (B). API gravity Fig.(11) also satisfies this fact.

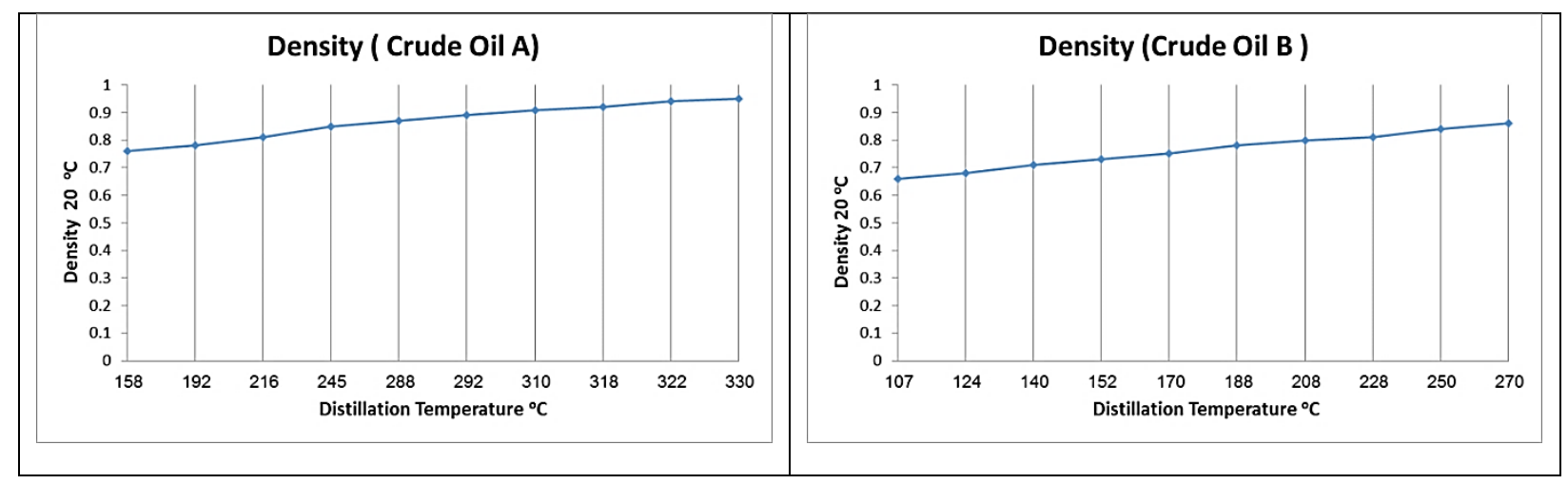

Fig.(10): Density distribution along distillation temperature for crude oils $A \& B$. 


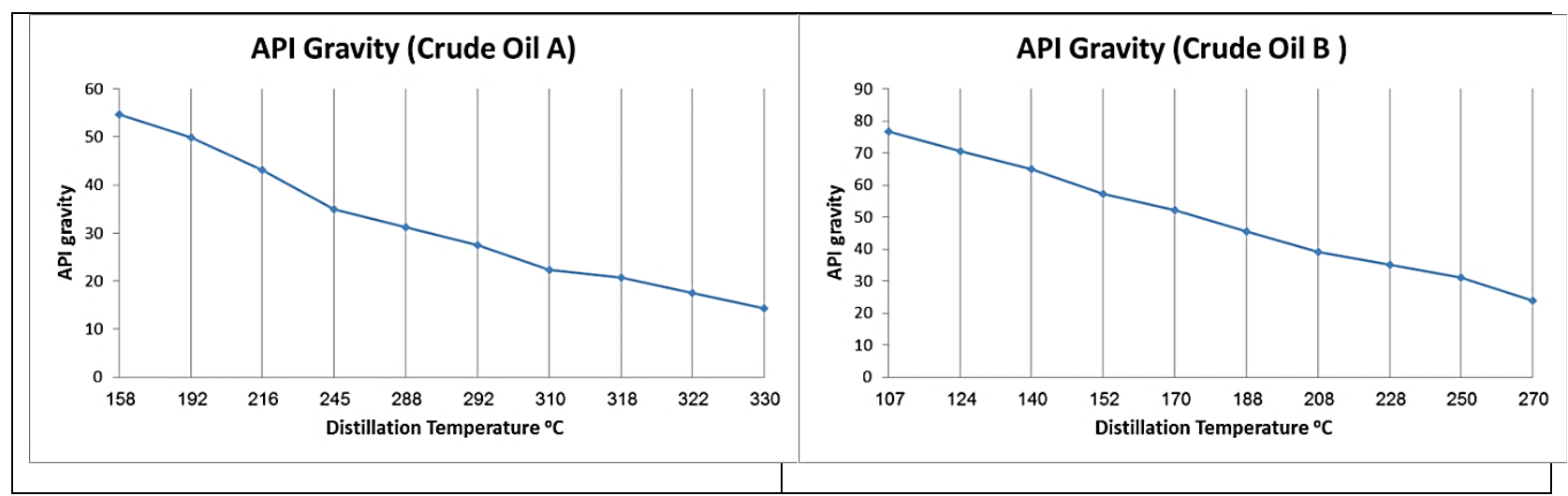

Fig.(11): API gravity distribution along distillation temperature for crude oils $A \& B$.

\section{Conclusion}

Although two samples were analyzed, but the indication of being considering the type (B) as light oil compared with type (A), so it is clear enough that oil type (A) must be excluded to protect refinery equipment from damages. Crude oil (B) is so suitable for processing according to physical properties: Boiling point, Density, Pour point, Surface tension and Aniline point in addition to the calculated results: API gravity, $\mathrm{Kw}$ factor and Correlation index and gives more valuable paraffinic components than naphthenic or aromatics compared with crude oil (A).

\section{Acknowledgements}

The authors acknowledge the Department of Chemistry, College of Science, Al-Nahrain University for their encouragement.

\section{References}

[1] Speight J.G., "The Desulfurization of Heavy Oils and Residua", $2^{\text {nd }}$ Edition. Marcel Dekker, New York, 1999.

[2] Jones D., Pujado P., "Handbook of petroleum processing", Dordrecht, The Netherlands: Springer, 2006.

[3] Gruse W.A., Stevens D.R., "Chemical Technology of Petroleum”, McGraw Hill Book Co.: New York, 1960.

[4] Olajire A.A., Oderinde R.A., "Nafta", 47, 259, 1996.

[5] Njeri H., "Industrial Chemistry", African Virtual University.

[6] Chang A.F., "Refinery Engineering" Integrated Process Modeling and Optimization First Edition, 2012.
[7] G lean E., James H., "Petrochemical Refining Technology and Economics" Fifth Edition.

[8] James G., "The Chemistry and Technology of Petroleum" Fourth Edition.

[9] Salem S., SPE, Kuwait Institute for Scientific Research, "Optimal Transformations for Multiple Regression", 2009.

[10] James A. M., Practical Physical Chemistry, Third edition, 1974.

[11]Ante J., "Petroleum Refining and Petrochemical Processes", Faculty of Chemical Engineering and Technology, University of Zagreb, 2012.

[12] Zhendi W., "Characteristics of Spilled Oils, Fuels, and Petroleum Products" EPA/600/R-03/072 July, 2003.

[13] Albahri T.A., "Octane Number and Aniline Point of Petroleum Fuels" Fuel Chemistry Division Preprints, 47(2), 710, 2002.

[14] Nedelchev A., "Boiling Point Distribution of Crude Oils Based on TBP AND ASTM D-86 Distillation Data, Petroleum \& Coal 53 (4) 275-290, 2011.

[15] RIVERO R., "The Exergy of Crude Oil Mixtures and Petroleum Fractions: Calculation and Application" Int.J. Applied Thermodynamics, 2 (3), 1999.

[16] Mall I.D., "Petrochemical process technology", New Delhi, Macmillan India 2007.

[17] Leffler WL., "Petroleum refining in nontechnical language" Tulsa, Oklahoma: Penn Well; 2000. 
[18] Standard test method for distillation of petroleum products at atmospheric pressure. ASTM Standard D 86-04b, Book of Standards Volume: 05.01. West Conshohocken (PA): American Society for Testing and Materials; 2004.

[19] Standard test method for distillation of crude petroleum (15-theoretical plate column). ASTM Test Method D-2892. West Conshocken (PA): ASTM Book of Standards, 2003.

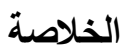

تم اختيار نوعين من النفوط الخام من مصفى الدورة

واختبارها من حيث الخواص الفيزيائية: درجة الغليان، الكثافة،

درجة الانسكاب ودرجة الانلين اضافة الى الخواص التي تم

حسابها من حيث (Kw, API,CI) من اجل تحديـد خـواص الاص

النفوط والمقارنه بينهما نم رسم منحنيات التقطير استتادا الى لى

طريقة التقطير (ASTM-2892) للنفوط الخام طي البحث

لحساب كميات ونسب المشتقات النفية المنتجه لاستخدامها

في دعم النتائج الاولية للخواص الفيزيائيه.

تنين من خلال النتائج بان خواص النفط الخام (A) هو

الاثقل والاكثر تركيز من حيث النفتينات والمواد الاروماتية

من الخام (B) وبنفس المفهوم فان الخام (B) اكثر برافيني

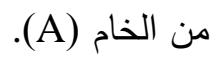

